\title{
Pappi Tomas
}

\section{A Review of Marilyn KrysL's How to ACCOMMODATE MEN}

Not often does the title of a book of stories seem to call out so strongly to a certain audience. And just as rarely does a fiction title imply a certain function for its pages. Invoking the spirit of the how-to manual in her second collection of stories, How to Accommodate Men, Marilyn Krysl-poet, fiction writer, and current director of the Creative Writing Program at the University of Colorado at Boulder-creates an expectation no doubt unfamiliar to many readers of short fiction, but one likely to pique their interest. I, myself, was curious. "What a strange title," I couldn't help wondering. "And just how does one accommodate men?" And who, we might ask, is this "one" in question, and who are these "men"? For my part, I would expect the audience for such a book, were it really a how-to, to be comprised of women. I'm thinking here of a mostly heterosexual audience. Krysl is, too, it seems, for all but the last of these thirteen stories portray women who relate themselves sexually to men. The exception, a nun in what sounds like the fifteenth century who clearly has eyes for a woman, her "guest" she calls her, with whom she spends many "nights in delicious darkness." There is one male narrator in this collection-more about him later.

Also unfamiliar is the way Krysl organizes her stories. She divides the book, as one might a book of essays, into sections-“Glamourpuss," "The Island," and "Eating God"-distributing, unevenly, the stories among them. The sections, each with a title quite unlike the others, tend to encompass a mood more than a topic, and their overall effect, as in a book of essays, is to grant a sense of order, to suggest connections among disparate parts. "Glamourpuss" announces the tone of most of the stories within it-ironic, blunt, "given to extremes," as one narrator puts it. "The Island" is just what it says-remote, mysterious, awash in its own weather, left to sink or swim in its isolated savagery. "Eating God" is yet another departure, lighter in some ways, to help us emerge from the book's dark middle.

How to Accommodate Men. Coffeehouse Press. 220 pp. $\$ 13.95$.

172 
If we continue imagining this book as a kind of how-to, we might see it as a series of object lessons, a string of cautionary tales which we, both men and women, should recognize, and of which we would do well to take heed. Appreciate those caregivers, one story scolds. Have compassion for those who have suffered, advises another. Reject violence, embrace tenderness, refuse to believe in enemies, look into the heart of your neighbor, accept the universe whole. There is little here to disagree with. And yet is this how we want our fiction to work on us? To prod us with morals, barrage us with archetypes? Of course not, and happily Krysl does not inflict such punishment. She has a moral vision, but also a playful heart.

And when she plays, it's the trying on of vocal disguises, costumes of style, that seems to be her favorite game. Note the stylistic difference between a story like "Laissez-Faire" that begins, "Frank holds a tie in each hand," and one like "Glamourpuss" that begins, "I am Gloria Innanna Aphrodite Hapshepsut Jones, and I have been interested in glamour as far back as I can remember." Or the curious alloy of voices within a single story like "Mercy," which starts off:

Where, where, damn it, is the queen! The little prince's mother, right now, while she can still save him? Is she in the pantry, eating bread and honey? Is she in the master bedroom stripping the kingsize bed, staring at the mattress, that white blank, site of black-andblue psyche's insomnia?

Notice also the drastic shunting through epochs, from the moment of creation in "Extinct Species," where two deities, male and female, cook up the universe together; to the absurd paranoia of the Red Scare in "The Girls of Fortress of America," with fallout shelters and madcap space races; to the zealous middle ages in "Eating God," where male "advisors" urge nuns to live on nothing but God, starving their way to sainthood. Through such pleasing variety, Krysl demonstrates who must accommodate men, what sorts of men these are, how one should or shouldn't respond to them, and when it is that one has no choice in the matter, and must do the best one can.

In two instances, the narrator is the wife of an accomplished public man, one a corporate executive in his sixties, the other an insecure middle-aged academic. Each relies on his wife to perform such image-nurturing tasks as choosing a necktie, preparing quick but chic hors d'oeuvres for an office 
shindig, attending said shindig looking sexy and sophisticated, buttering up colleagues with ego-affirming remarks, setting aside a number of such remarks for him when they arrive home, where she can offer him other things, too. But whereas the corporate wife has invested her emotional energy into her selfish husband, receiving no nourishment in return, the academic wife does not allow emotion to figure in any of it, but simply takes a kind of selfsatisfied, professional pleasure in her ability to assist, organize, direct, bolster. The first woman ends up feeling empty, while her husband thrives; the second thrives on making her husband helpless, leaving him, finally, hollow and juiceless, like a spider does its prey.

In the story "Glamourpuss," the heroine is likewise predatory, but not coldly so. She is one of these pagan goddesses that Krysl seems to enjoy depicting, one foot in the temporal, one in the eternal, whose work it is both to help the world prosper and to enjoy its pleasures. But every privilege has its obligations, its sacrifices. "Fructifying was the trade I was learning," she says, "but now that I'd got the first part down, it occurred to me step two might be harder. ... I had dallied on that bed of roses without responsibilities. Now I'd have to assume throne and scepter." So she rips out the heart of each man she enjoys, but not to sup on it herself; instead she goes her "appointed rounds, sprinkling his blood through the wheat, corn, barley." I like Krysl's method of turning things upside down, pulling the inside out. When she imagines, she is extreme, like her characters.

She allows the men in her stories to expand as well, to move past limits commonly assigned them. By the end of the book, especially after a visit to "The Island," where military violence shoots down male and female alike, it is clear that "Men" is more a category of behavior, a way of being- "The Thing Around Them," as one story here is titled-than a designation of gender. A boy is perhaps likely but not destined to become a violent, bitter father; a soldier with eyes glazed over; an egomaniac; an oaf who can't express himself tenderly; in short, a "Man."

In "Mine" (the sort that explodes), the last story of "The Island," Krysl prepares us for the more forgiving, more compassionate atmosphere of "Eating God," the book's final section. Here, she gives us Captain Mendis, a friendly soldier stuck at an outpost; stuck, muses his long-distance lover Elena, "in the heat, on that plain at the edge of the jungle, miles from the city." So he calls her every night. "I couldn't sleep," he says: 
I thought of you lying in bed. I was thinking how loose your body must be when you're lying down. I was thinking how it would feel to touch your skin while you sleep. I wonder what you smell like right now. Tell me.

In the final story "Eating God," it's Christ himself that Krysl revises into a more progressive sort of character. He visits the narrator, an inspired nun, comforts her, encourages her, endows her with extraordinary (indeed holy) gifts of language and delight. "Catherine," he announces to her one evening in her private chamber, "you shall begin to teach men." And she does, though they don't like it, are not ready to learn from a woman, especially one who receives a female "guest" in her chamber at night. Yet to eat God, Krysl suggests, is to consume all of life, for "God's body is everywhere," says the narrator, "in the air and in the water, in the apple and beside the apple." In prison, she spends her dying moments eating God, and being eaten in return.

My lasting impression of Krysl's book, however, is of "Distant Lights on Water," the first story of her final section. Clayton, a fashion designer, is Krysl's strongest case for the existence of God in all things, whether man or woman. When Clayton tries without success to improve conditions at a sweatshop owned by his company, he wonders if he has done his best, if his best means no more than expressing dissent before the board of executives. Krysl herself, we learn from the book squib, has encountered the fray of activism and volunteer caregiving, from Peace Brigade International in Sri Lanka, to Kalighat Home for the Destitute and Dying. From these experiences, one imagines, she has acquired the open-hearted, clear-sighted, uncompromising eye through which her stories are rendered. Now, like this fellow Clayton, she is back among us and expressing her own form of dissent, sharing her own brand of advice. Is she doing her best? If not, she couldn't do much better. 